\title{
Changes in jökulhlaup sizes in Grímsvötn, Vatnajökull, Iceland, 1934-91, deduced from in-situ measurements of subglacial lake volume
}

\author{
Magnús T. Gudmundsson, Helgi Björnsson and Finnur Pálsson \\ Science Institute, University of Iceland, Dunhaga 5, IS-107 Reykjavik, Iceland
}

\begin{abstract}
A record of volumes of jökulhlaups from the subglacial Grímsvötn lake, Vatnajökull, Iceland, has been derived for the period 1934-91. The change in lake volume during jökulhlaups is estimated from the lake area, ice-cover thickness and the drop in lake level. The jökulhlaup volumes have decreased gradually during this period of low volcanic activity and declining geothermal power. The two jökulhlaups in the 1930s each discharged about $4.5 \mathrm{~km}^{3}$ (peak discharge 25-30 $\times 10^{3}$ $\mathrm{m}^{3} \mathrm{~s}-1$ ). In the $1980 \mathrm{~s}$, jökulhlaup volumes were $0.6 .-1.2 \mathrm{~km}^{3}$ (peak discharge $2 \times 10^{3}$ $\mathrm{m}^{3} \mathrm{~s}^{-1}$. The lake level required to trigger a jökulhlaup has risen as an ice dam east of the lake has thickened. Water flow in a jökulhlaup ceases when the base of a floating ice shelf covering Grímsvötn settles to about $1160 \mathrm{~m}$ a.s.l. Apparently, the jökulhlaups are cut off when the base of the ice shelf collapses on to a subglacial ridge bordering the lake on its eastern side. The decline in melting rates has resulted in a positive mass balance of the $160-170 \mathrm{~km}^{2}$ Grímsvötn ice-drainage basin. Comparison of maps shows that the average positive mass-balance rate was $0.12 \mathrm{~km}^{3} \mathrm{a}^{-1}(25 \%$ of the total accumulation) in the period 1946 87. A gradually increasing positive mass balance has prevailed since 1954, reaching $0.23 \mathrm{~km}^{3} \mathrm{a}^{1}$ in $1976-86$ (48\% of total accumulation).
\end{abstract}

\section{INTRODUCTION}

The subglacial, geothermally sustained, Grímsvötn lake in Vatnajökull, Iceland (Fig. 1), is a well-known source of jökulhlaups (Thorarinsson, 1953, 1965, 1974; Rist, 1955; Björnsson, 1974, 1988, 1992) and various data from this type locality have played an important role in studies of the triggering mechanism and drainage of jökuhlaups (Thorarinsson, 1953; Glen, 1954; Björnsson, 1974, 1988, 1992; Nye, 1976; Spring and Hutter, 1981; Clarke, 1982). This paper presents revised data on the volumes of jökulhlaups from lake Grímsvötn for the last 60 years and describes how the volumes were derived. The data have already been used in recent studies of the simulation of the jökulhlaups (Björnsson, 1992), for the estimate of the volatile release rates from Grímsvötn (Ágústsdóttir and others, 1992) and for re-evaluation of the geothermal power in the Grímsvötn caldera Björnsson and Gudmundsson, 1993).

The first crude estimate of the volume of a Grímsvötn jökulhlaup $\left(10 \mathrm{~km}^{3}\right)$ was made by Nielsen (1937) after the 1934 event. With time, progressively better data have been collected and increasingly more sophisticated methods have been applied. The approaches used may be listed as follows:

1. Prior to 1954 , the discharge of jökulhlaups was estimated from eyewitness accounts together with rough mass-balance estimates for the Grímsvötn drainage basin, assuming steady-state conditions.
From these data, hydrographs were drawn for some of the jökulhlaups (Thorarinsson, 1953, 1974). The volume drained in the largest jökulhlaups (in 1934 and 1938) was estimated to have been about $7 \mathrm{~km}^{3}$ (Thorarinsson, 1974).

2. In the period $1954-72$, the Manning equation was used to estimate discharge of jökulhlaups and their hydrographs. (The Manning equation (e.g. Chow, 1964) relates the velocity of water flow in an open channel to the depth of the channel, the gradient along the direction of flow and the roughness of the channel.) These estimates yielded a total volume in the range $2.8-3.5 \mathrm{~km}^{3}$ for the four jökulhlaups that occurred during this period (Rist, 1955, 1973, 1990).

3. After construction of bridges across the rivers on the Skeidarársandur outwash plain in 1974, direct measurements of water depth and velocity in the flood channel could be made. The volume drained in the five jökulhlaups since 1976 has varied from $0.55 \mathrm{~km}^{3}$ to $1.9 \mathrm{~km}^{3}$ (Rist, 1984; Kristinsson and others, 1986; Pálsson and others, 1992; personal communication from S. Zóphóníasson, 1993).

4. For the jökulhlaup of 1986, Björnsson (1988) evaluated the volume of water drained out of Grímsvötn from the changes in lake geometry during the jökulhlaup. This approach was made possible through the availability of data on bedrock 


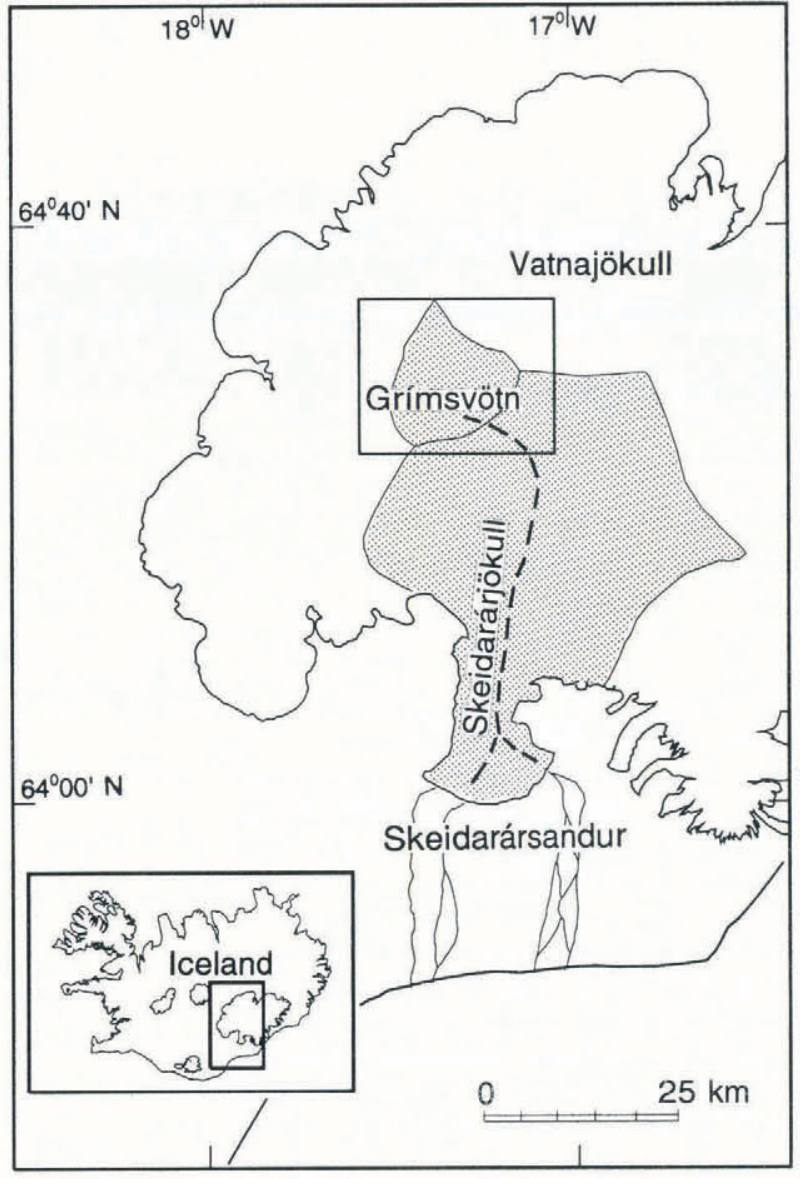

Fig. 1. The Vatnajökull ice cap. The drainage basins of Skeidarárjökull and Grimsvöln are shaded. The approximate subglacial path of the jökulhlaups is shown by the broken line. The rectangle indicales the area shown on Figures 2, 3, 8 and 9.

topography acquired by radio-echo soundings and seismic reflection in 1987 (Björnsson, 1988; Gudmundsson, 1989).

Here, we present a record of lake drainage, extending back to 1934, using the approach of Björnsson (1988). Furthermore, we compare the volumes drained in jökulhlaups with data on mass balance for the Grímsvötn ice-drainage basin.

\section{THE GRÍMSVÖTN AREA}

Extensive studies of the geometry of the Grímsvötn area (Figs 2 and 3 ) have been described in recent years (Björnsson, 1974, 1988; Gudmundsson, 1989; Björnsson and others, 1992). The lake is located within the caldera complex of the Grimsvötn volcano in the western part of the Vatnajökull ice cap (Figs 1 and 2). Three caldera structures have been identified (Fig. 3), ranging in area from 11 to $20 \mathrm{~km}^{2}$ Gudmundsson, 1992). The total heat released from the volcano in the period 1922 91 was $8.1 \times 10^{18} \mathrm{~J}$ (see Björnsson and Gudmundsson, 1993), yielding an average heat output of $3720 \mathrm{MW}$. However, this average value is misleading, as the power has varied by an order of magnitude over this period, with a high of
$11600 \mathrm{MW}$ in 193438 and a low of $1600 \mathrm{MW}$ in 1976 82. These changes in thermal output are attributed to variations in volcanic activity (Björnsson and Gudmundsson, 1993).

The Grímsvötn geothermal area has created a depression in the ice surface over the caldera region. This depression has a diameter of $10 \mathrm{~km}$ and a depth of about $300 \mathrm{~m}$ (Fig. 2). The ice thickness in the area is, on average, $300-500 \mathrm{~m}$ and in recent years the floating ice cover of the lake has been $230-260 \mathrm{~m}$ thick Björnsson, 1988). The floating-ice cover has the characteristics of an ice shelf; its interior parts are flat, floating in hydrostatic equilibrium, and the margins are marked by an abrupt change in surface slope. To the south and west, the lake is bordered by the caldera walls. As the lake level rises during the intervals between jökulhlaups, the lake expands towards the north and northeast.

The mechanism of Grímsvötn jökulhlaups and their general characteristics have been described by Björnsson (1974, 1988, 1992) and only a brief summary is given here. The lake is contained by a potential pressure barrier of the ice surrounding the depression and the lowest breach in the ice surface occurs to the east of the lake (Fig. 2 ). This low in the barrier is termed the ice dam. The triggering mechanism of Grímsvötn jökulhlaups has not been fully explained. Jökulhlaups occur at a lake level considerably lower than required to float the ice dam. At the start of most jökulhlaups the ice-overburden pressure at the ice dam exceeds the subglacial water pressure maintained by the lake by 5-7 bar. Björnsson (1988) suggested this might be due to weaknesses in the dam caused by basal ice movement. The jökulhlaups do not drain the lake completely as they usually terminate abruptly when the lake level has fallen by about $100 \mathrm{~m}$.

\section{CHANGES IN LAKE VOLUME AND ESTIMATES OF THE VOLUME OF JÖKULHLAUPS}

\section{Lake geometry}

The volume of water that is drained from the subglacial lake can be estimated from changes in lake level during jökulhlaups and the thickness and areal extent of the floating ice shelf.

The extent of the subglacial lake may be determined from that of the flat ice shelf floating on the lake. Moreover, crevasses formed at the margins of the ice shelf during jökulhlaups demarcate the margins of the lake prior to the event. This was confirmed by field studies during the jökulhlaup of 1991 and by comparing air photographs with maps made after the jökulhlaups in 1945, 1960 and 1986. Hence, vertical air photographs, taken shortly after the termination of jökulhlaups in $\mathbf{1 9 4 5}$, $1954,1960,1972,1983$ and 1986 were used to determine the extent of the lake (Fig. 4).

The lake level has been measured annually since 1955 by the Iceland Glaciological Society. In most years, it could be measured directly in patches of open water along the western or southern hillslopes. The measurements have been done by optical or barometric levelling using benchmarks of known height on the hillslopes at the margins of the main caldera. In addition, intermittent 


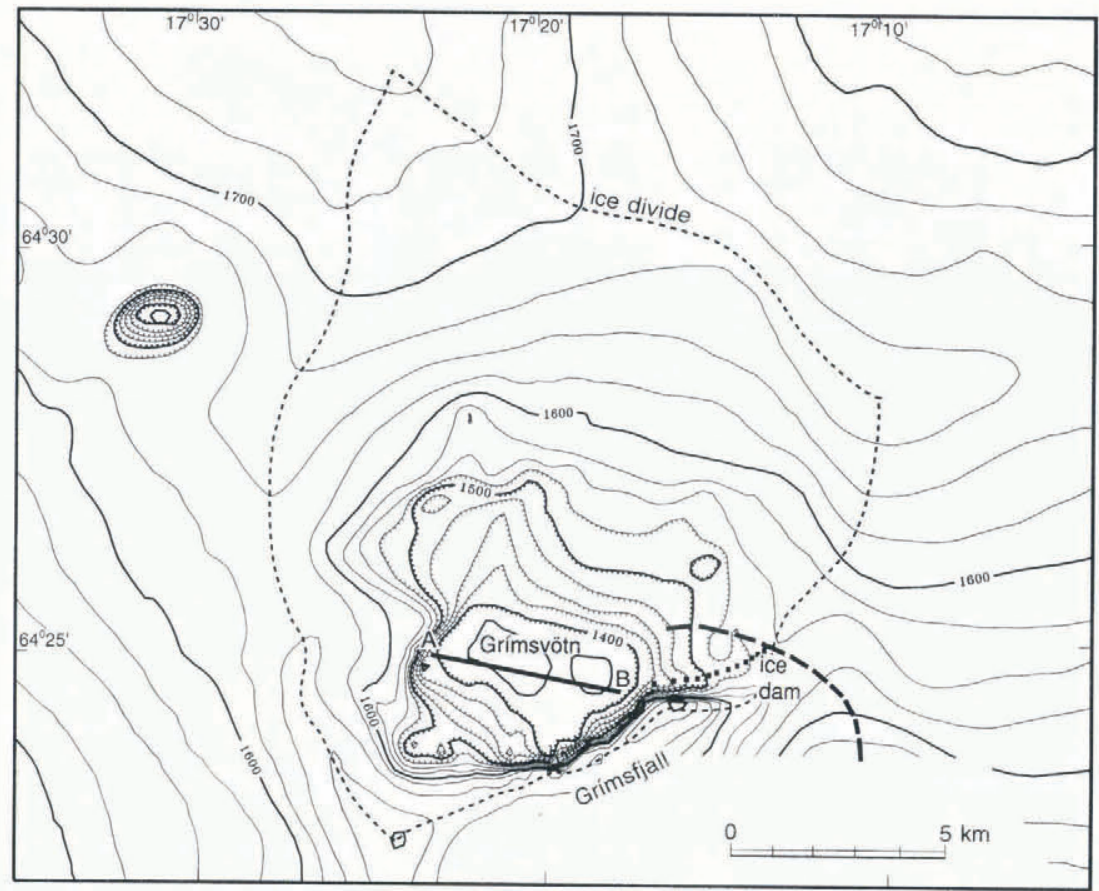

Fig. 2. The Grimsvötn area as mapped with precision barometry in June 1987 (contour interval $25 \mathrm{~m}$ ). The margins of the $160 \mathrm{~km}^{2}$ ice-drainage basin are shown. The flat area al $1400 \mathrm{~m}$ elevation is an ice shelf covering the subglacial lake (of $10 \mathrm{~km}^{2}$ ). The thick dashed and dotted lines mark the subglacial paths of jökulhlaups. The thick dashed line is considered to be the path of most jökulhlaups (Bjönsson, 1988). The lake level at the lime of the survey was 1374 ma.s.l. The measurements of ice-shelf thickness shown in Figure 6 were made along the profile A B. Rocks are exposed in the caldera walls that border the lake toward the south, the steep northern slopes of the ridge Grimsfjall.

measurements of the ice-shelf elevation and lake level were made in the period 1935-53 Áskelsson, 1936; Thorarinsson, 1953; personal communication from $\mathrm{S}$. Sigurdsson, 1946) and photogrammetry was used to determine the lake level in 1945, 1946 and 1954. Gaps remaining in the record of lake level in the period 1934 55 were filled with estimates based on photographs taken by expeditions that inspected the area, either on foot or

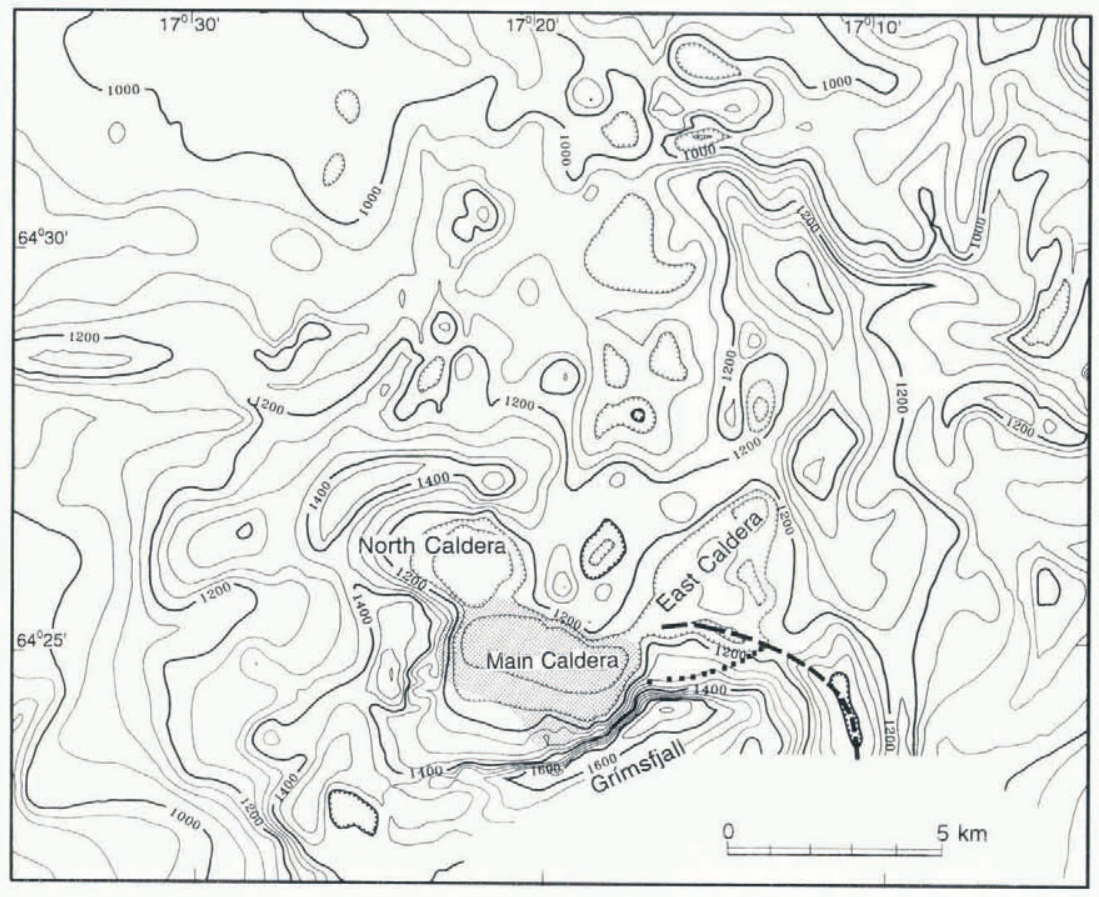

Fig. 3. A bedrock map of the Grimsvötn area (contour interval $50 \mathrm{~m}$ ) as mapped by radio-echo sounding and seismic reflection in 1987 (Björnsson, 1988; Gudmundsson, 1989). The area covered by the subglacial lake in 1987 is shaded. The rock face exposed on the southeastern margin of the caldera is roughly defined by the $1600 \mathrm{~m}$ contour on the ridge Grimsfjall. The inferred pathways of jökulhlaups are shown in Figure 2. 

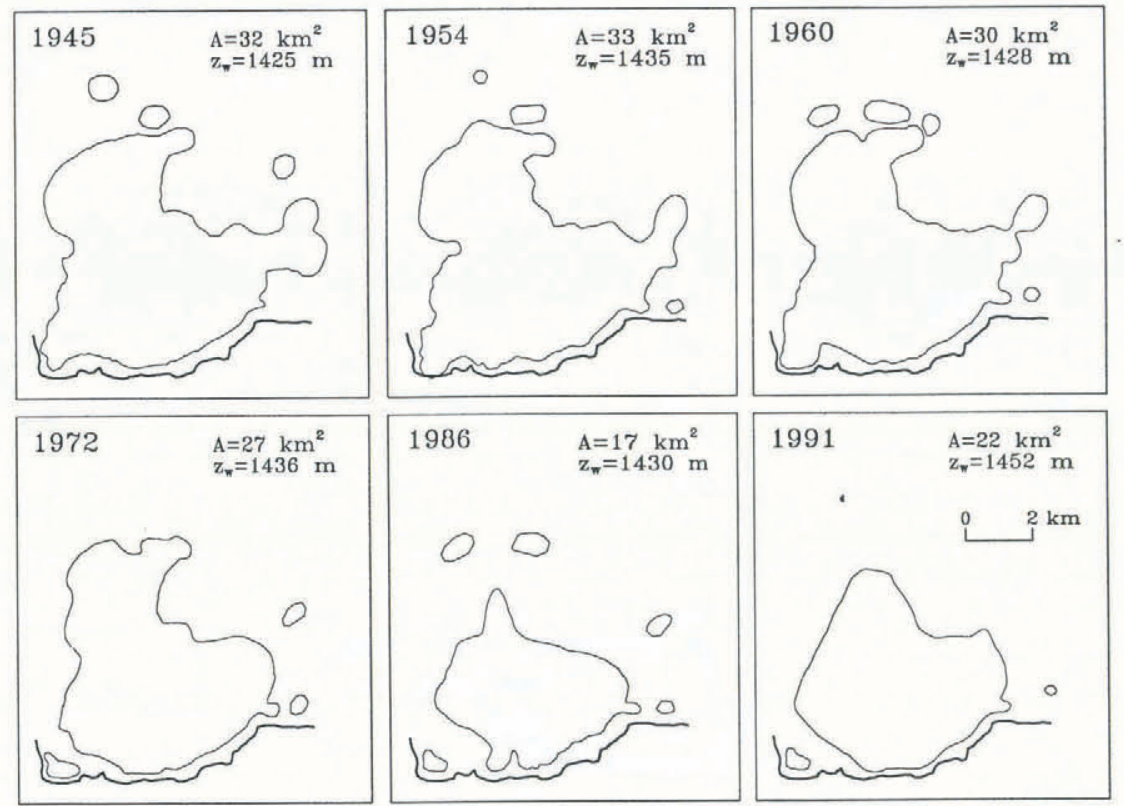

Fig. 4. Margins of the subglacial lake at the start of the jökulhlaups in 1945, 1954, 1960, 1972, 1986 and 1991. The margins were located on vertical air pholographs showing the large crevasses which formed above the grounding line during the jökulhlaups. A denotes the lake area and $z_{\mathrm{w}}$ the lake level.

from the air. These photographs show either the rock face at the southeastern margin of the caldera or the slopes at its western margin (Figs 2 and 3). Open water was observed along these slopes and its level could be estimated by reference to landscape features of known height. In these various ways, we have extended the lakelevel record back to 1934 (Fig. 5).

\section{Thickness of the ice shelf}

The thickness of the ice shelf has been measured several times since 1976 by using radio-echo soundings (Ferrari and others 1976; Björnsson, 1988, unpublished data). In most years between 1958 and 1975, concurrent with the lake-level measurements, profiles (A-B; see Fig. 2) were optically or barometrically levelled across the floating ice shelf (Thorarinsson, 1965; Björnsson, 1988). These surface profiles may be used to calculate the thickness of the ice shelf provided a reliable estimate of the bulk density of the floating ice can be made. Björnsson (1988) used the surface profiles to calculate ice thickness using a constant density value of $900 \mathrm{~kg} \mathrm{~m}^{3}$ for all the profiles. The calculations showed a gradual increase in thickness between 1960 and 1980. A more detailed study of this change in thickness is now possible as better data have been gathered on the bulk density of the ice shelf and the density stratification of its uppermost $30 \mathrm{~m}$.

The bulk density, $\rho_{\mathrm{b}}$, of the ice shelf may be calculated using $\rho_{\mathrm{b}}=\left(1-\Delta z / z_{\mathrm{t}}\right) \rho_{\mathrm{w}}$ where $\Delta z$ is the difference in elevation between the ice-shelf surface and the lake level, $z_{\mathrm{t}}$ is the total thickness of the ice shelf and $\rho_{\mathrm{w}}=$ $1000 \mathrm{~kg} \mathrm{~m}^{-3}$ is the density of water. In the period $1983-$ 91 , when $\Delta z$ was $27.5-28 \mathrm{~m}$, radio-echo soundings showed the thickness of the ice shelf in the central area to be about $250 \mathrm{~m}$, giving a mean bulk density of $889 \pm 4 \mathrm{~kg} \mathrm{~m}^{-3}$. An independent measurement was obtained by drilling in 1991, which gave $z_{\mathrm{t}}=$ $252 \pm 2 \mathrm{~m}$ and $\Delta z=28.2 \pm 0.2 \mathrm{~m}$, yielding a bulk density of $888 \pm 1 \mathrm{~kg} \mathrm{~m}^{-3}$. An ice core from the uppermost $25 \mathrm{~m}$ of the ice shelf, extracted in June 1993, showed

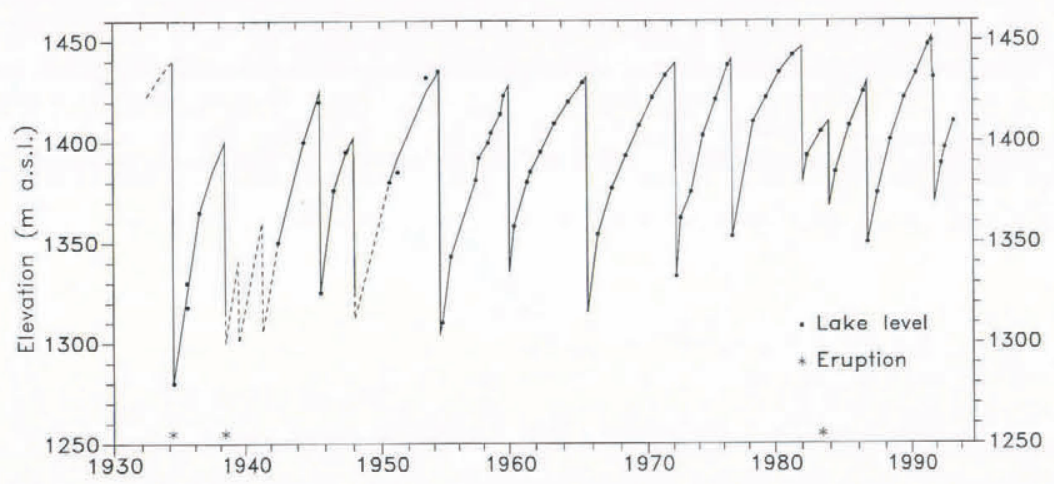

Fig. 5. The lake level in Grimsvötn over the period 1934 93. The largest drop in lake level occurred in 1934, 150-160 m. No lake-level measurements exist between 1938 and 1942. However, the occurrence of the jökulhlaups in 1939 and 1941 is well documented (Thorarinsson, 1974). The dotted curve shown in 1938 42 and the minimum in 1948 are estimated from the rise of the lake level in 193438 and $1945-48$. 
a roughly linear increase in density with depth, and extrapolation suggests that the ice has acquired a density of about $900-910 \mathrm{~kg} \mathrm{~m}^{-3}$ at $30 \mathrm{~m}$. These data indicate that the ice shelf may be divided into two layers, a $30 \mathrm{~m}$ surface layer with a mean density $\rho_{1}=710 \mathrm{~kg} \mathrm{~m}^{-3}$ and an ice layer below $30 \mathrm{~m}$ depth with a constant density, $\rho_{2}$. Since the thickness and bulk density of the ice shelf in recent years is known, $\rho_{2}$ can be found from $\rho_{\mathrm{b}}=$ $\left(z_{1} \rho_{1}+z_{2} \rho_{2}\right) / z_{\mathrm{t}}$ where $z_{1}=30 \mathrm{~m}$ and $z_{2}=z_{\mathrm{t}}-z_{1}$. Using $\rho_{\mathrm{b}}=888 \mathrm{~kg} \mathrm{~m}^{3}$ and $z_{\mathrm{t}}=250 \mathrm{~m}$, one obtains $\rho_{2}=$ $912 \mathrm{~kg} \mathrm{~m}^{-3}$. At times of known lake level, this density model may be used to convert data on surface elevation into thickness values provided the thickness and density of the surface layer has not changed with time. Indeed, seismic experiments on the ice shelf carried out in 1951 and 1987 Joset and Holtzscherer, 1954; Gudmundsson, 1989 ) indicate a similar structure of the surface layer, suggesting that application of the density model to the ice shelf in the period under consideration is justified.

The results suggest that the bulk density of the ice shelf has increased from $875880 \mathrm{~kg} \mathrm{~m}^{-3}$ prior to 1960 to about $890 \mathrm{~kg} \mathrm{~m}^{-3}$ in the $1980 \mathrm{~s}$. This increase was caused by a general increase in the thickness of the ice shelf. Along the surface profile surveyed (A B in Fig. 2) the mean thickness changed from about $150 \mathrm{~m}$ in 1960 to 220 $230 \mathrm{~m}$ in 1980 (Fig. 6). However, the central part of the ice shelf was thicker, $170-190 \mathrm{~m}$ prior to 1960 , rising to $250-260 \mathrm{~m}$ in the $1980 \mathrm{~s}$.

\section{Volume of jökulhlaups}

The data on bedrock topography, lake size, lake level and the thickness of the ice shelf make it possible to estimate the volume of the lake at any given time (Fig. 7). The volumes drained during jökulhlaups in the period 1934 91 (Table 1) are obtained by subtracting the lake volume at the end of a jökulhlaup from the volume at its start. Measurements in Grímsvötn have shown that the temperature of the lake water is close to zero (for example, $0.05-2.2^{\circ} \mathrm{C}$ in 1991$)$. Therefore, water produced by melting in the jökulhlaup tunnel due to advected heat is negligible compared to the total volume drained. However, the temperature of jökulhlaup water at the outlet has consistently been shown to be at $0.0^{\circ} \mathrm{C}$ (Björnsson, 1992) and it can therefore be assumed that all potential energy is converted to heat and dissipated by friction in the jökulhlaup tunnel during the transport from $1400 \mathrm{~m}$ elevation at Grímsvötn to $100 \mathrm{~m}$ at Skeidarársandur. It can therefore be calculated that melting of the tunnel walls will increase the volume of the water discharged by $4 \%$. This effect has been accounted for in the final value of the volume of the jökulhlaups in Table 1.

The peak discharge of some of the jökulhlaups is estimated in the final column in Table 1. For some of the jökulhlaups before 1976, hydrographs had been drawn by Thorarinsson (1974) and Rist (1955, 1990), assuming higher total volumes discharged than obtained here. The peak-discharge values in Table 1 are found by linearly scaling down these earlier estimates. For jökulhlaups after 1976, the values are those given by Rist (1984), Kristinsson and others (1986), Pálsson and others (1992) and Zóphóníasson (personal communication, 1993). Björnsson (1992) used these data to derive an

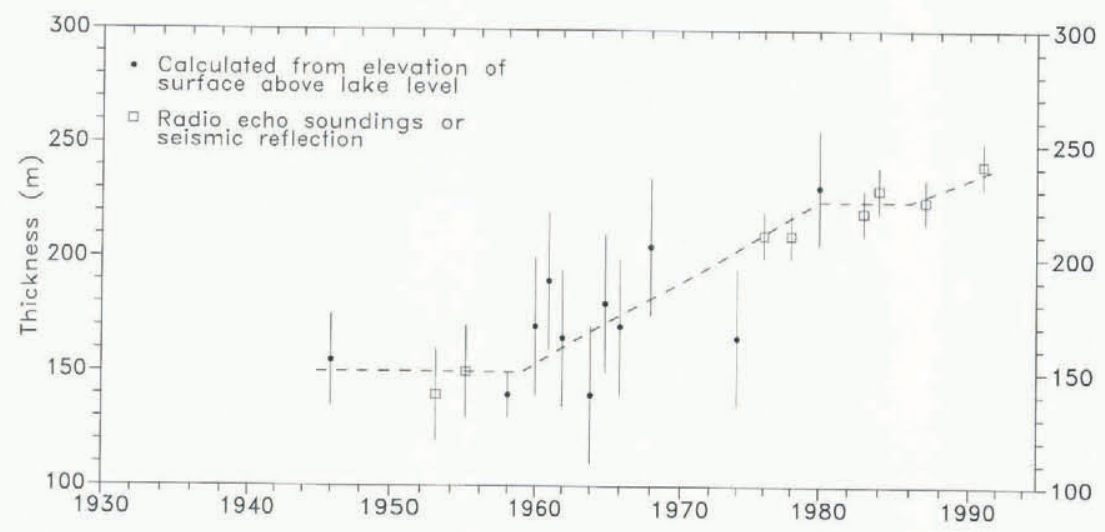

Fig. 6. Mean ice-shelf thickness, 1946-91, along profile A-B (see Figure 2 for location).

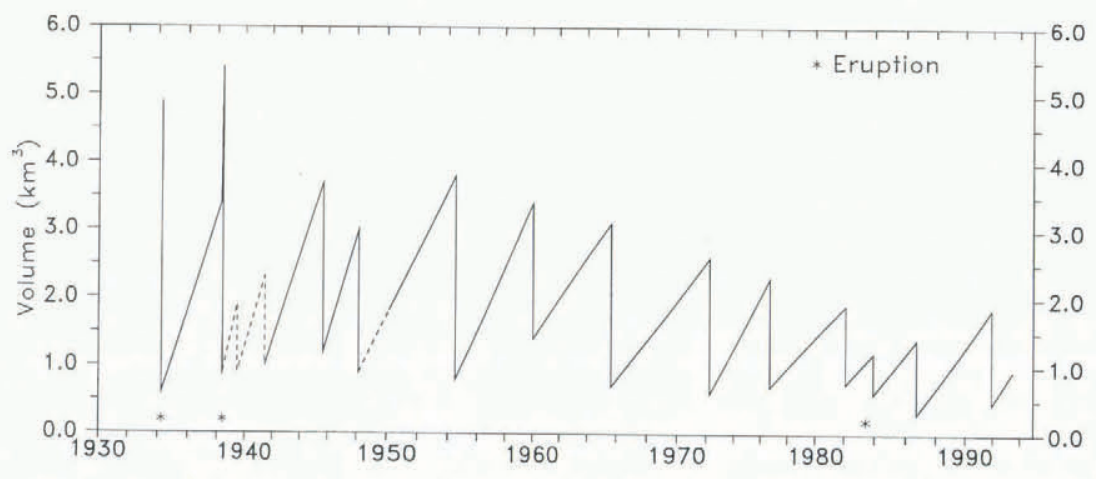

Fig. 7. Volume of the Grímsvötn lake 193493. 
Table 1. Characteristics of jökulhlaups from Grimsvötn in 1934-91

\begin{tabular}{|c|c|c|c|c|c|c|c|c|c|c|}
\hline \multirow[t]{3}{*}{ Tear } & \multirow[t]{2}{*}{ Lake area } & \multirow{2}{*}{$\begin{array}{l}\text { Ice-shelf } \\
\text { thickness }\end{array}$} & \multicolumn{3}{|c|}{ Lake level } & \multicolumn{3}{|c|}{ Lake volume } & \multirow{2}{*}{$\begin{array}{l}\text { Volume } \\
\text { drained }\end{array}$} & \multirow{2}{*}{$\begin{array}{c}\text { Peak dis- } \\
\text { charge }\end{array}$} \\
\hline & & & Initial & Final & Change & Initial & Final & Change & & \\
\hline & $\mathrm{km}^{2}$ & $\mathrm{~m}$ & \multicolumn{2}{|c|}{ ma.s.l. } & $\mathrm{m}$ & $\mathrm{km}^{3}$ & $\mathrm{~km}^{3}$ & $\mathrm{~km}^{3}$ & $\mathrm{~km}^{3}$ & $10^{3} \mathrm{~m}^{3} \mathrm{~s}^{-1}$ \\
\hline 1934 & 37 & 150 & 1440 & 1280 & 160 & 4.9 & 0.6 & 4.3 & 4.5 & $25-30$ \\
\hline 1938 & $27+15^{+}$ & 150 & 1400 & $1300^{*}$ & $100^{*}$ & 5.4 & 0.9 & 4.5 & 4.7 & $25-30$ \\
\hline 1939 & $<25$ & 150 & $1340^{*}$ & $1300^{*}$ & $40^{*}$ & 1.9 & 0.9 & 1.0 & 1.0 & - \\
\hline 1941 & $<25$ & 150 & $1360^{*}$ & $1305^{*}$ & $55^{*}$ & 2.3 & 1.0 & 1.3 & 1.4 & - \\
\hline 1945 & 32 & 150 & 1425 & 1325 & 100 & 3.7 & 1.2 & 2.5 & 2.6 & $8-10$ \\
\hline 1948 & 27 & 150 & 1400 & $1310^{*}$ & $90^{*}$ & 3.0 & 0.9 & 2.1 & 2.2 & - \\
\hline 1954 & 33 & 150 & 1435 & 1305 & 130 & 3.8 & 0.8 & 3.0 & 3.2 & 10 \\
\hline 1960 & 30 & 155 & 1428 & 1338 & 90 & 3.4 & 1.4 & 2.0 & 2.1 & $5-6$ \\
\hline 1965 & 29 & 175 & 1432 & 1317 & 115 & 3.1 & 0.7 & 2.4 & 2.5 & 6 \\
\hline 1972 & 27 & 195 & 1436 & 1330 & 106 & 2.6 & 0.6 & 2.0 & 2.1 & 5 \\
\hline 1976 & 26 & 210 & 1439 & 1350 & 89 & 2.3 & 0.7 & 1.6 & 1.7 & $3.5-4$ \\
\hline 1982 & 22 & 230 & 1447 & 1380 & 67 & 1.9 & 0.75 & 1.15 & 1.2 & 2 \\
\hline 1983 & 15 & 230 & 1412 & 1370 & 42 & 1.2 & 0.6 & 0.6 & 0.6 & 0.6 \\
\hline 1986 & 17 & 230 & 1430 & 1350 & 80 & 1.4 & 0.3 & 1.1 & 1.15 & 2 \\
\hline 1991 & 22 & 230 & 1452 & 1370 & 82 & 1.85 & 0.45 & 1.4 & 1.45 & 2 \\
\hline
\end{tabular}

\footnotetext{
*Value obtained by extrapolating over more than 1 year or estimated without observations. For jökulhlaups since 1945 the accuracy of lake volumes is $15-17 \%$, and that of volumes drained is 10-12\%. Corresponding values before 1945 are $20-25 \%$ and $15-20 \%$.

${ }^{\dagger}$ The $15 \mathrm{~km}^{2}$ area subsided above a volcanic fissure to the north of the lake.
}

empirical relation between peak discharge and total volume for Grímsvötn jökulhlaups.

For the period after 1945, the errors in lake size and in the drop in lake level are considered to be $3-4 \%$ but that in ice-shelf thickness is $8-10 \%$. The resulting maximum error in volume stored in the lake is $15-17 \%$. The error in volume drained in the jökulhlaups is less sensitive to error in ice-shelf thickness, hence, the maximum error in volume drained is only $10-12 \%$. The uncertainties prior to 1945 are $20 \%$ in lake volume and $15 \%$ in jökulhlaup volume. The internal consistency of the record is considerably better as the largest source of error, a systematic error in ice thickness, would shift all volume values either up or down.

\section{LONG-TERM MASS BALANGE}

In previous studies of the Grímsvötn basin, the mass of ice melted in Grímsvötn has been assumed to be in long-term balance with the input of mass to the ice-drainage basin (Thorarinsson, 1953, 1974; Björnsson, 1974, 1988). This assumption was justified by the long-term existence of the Grímsvötn depression. Available data on the mass balance, although indeed scarce, did not disprove the assumption as a valid first approximation. Over the last two or three decades, however, a positive mass balance of the surrounding glacier has been suspected due to the cooling of the geothermal system, as expressed by the shrinkage of the lake area and thickening of the ice shelf (Björnsson, 1988; Björnsson and Gudmundsson, 1993). Here, we present data on the long-term mass balance of the ice-drainage basin that are more detailed than published previously.

\section{Mass balance of the ice-drainage basin}

The average annual precipitation in the Grímsvötn area for the period 1950-85 was $3.0 \pm 0.3 \mathrm{ma}^{-1}$ (Björnsson, $1985,1988)$. This precipitation falls almost entirely as snow, so the total accumulation rate within the icedrainage basin (averaging $170 \mathrm{~km}^{2}$ in the period 1945 65 , declining to an average of $160 \mathrm{~km}^{2}$ in $1965-85$ ) was $0.48-0.50 \mathrm{~km}^{3} \mathrm{a}^{-1}$. The average rate of melting by meteorol-ogical processes over the last several years was estimated to be $0.08 \mathrm{~km}^{3} \mathrm{a}^{-1}$ (Björnsson, 1988) but from 1935 to 1960 it was $0.11 \mathrm{~km}^{3} \mathrm{a}^{-1}$ (Gudmundsson and Björnsson, 1991). Comparison of maps (Figs 2 and 8 ), on the other hand, shows that the net mass balance of the ice-drainage basin was positive over the period 1946 87 , by $0.12 \pm 0.02 \mathrm{~km}^{3} \mathrm{a}^{-1}$, or $0.75 \mathrm{~m} \mathrm{a}^{-1}$ averaged over the basin $(25 \%$ of total accumulation). Figure 9 shows the difference in surface elevation between the two maps of the Grimsvötn basin, of 1946 (Fig. 8) and 1987 (Fig. 2 ), at about the same lake level, 1376 and $1374 \mathrm{~m}$ a.s.l., respectively. The ice thickness in the surroundings of the lake increased by $50-100 \mathrm{~m}$ as the area of the ice shelf (at this lake level) decreased from 23 to $10 \mathrm{~km}^{2}$. The increase in the ice volume due to this change in ice-surface elevation was $3.7 \pm 0.7 \mathrm{~km}^{3}$. In addition, a volume of $1.5 \pm 0.3 \mathrm{~km}^{3}$, occupied by water in 1946, had been replaced by ice in 1987 (assuming a bulk density of the ice shelf of $880 \mathrm{~kg} \mathrm{~m}^{-3}$ in 1946). Hence, the total increase in ice volume was $5.3 \pm 0.8 \mathrm{~km}^{3}$ (equivalent to 


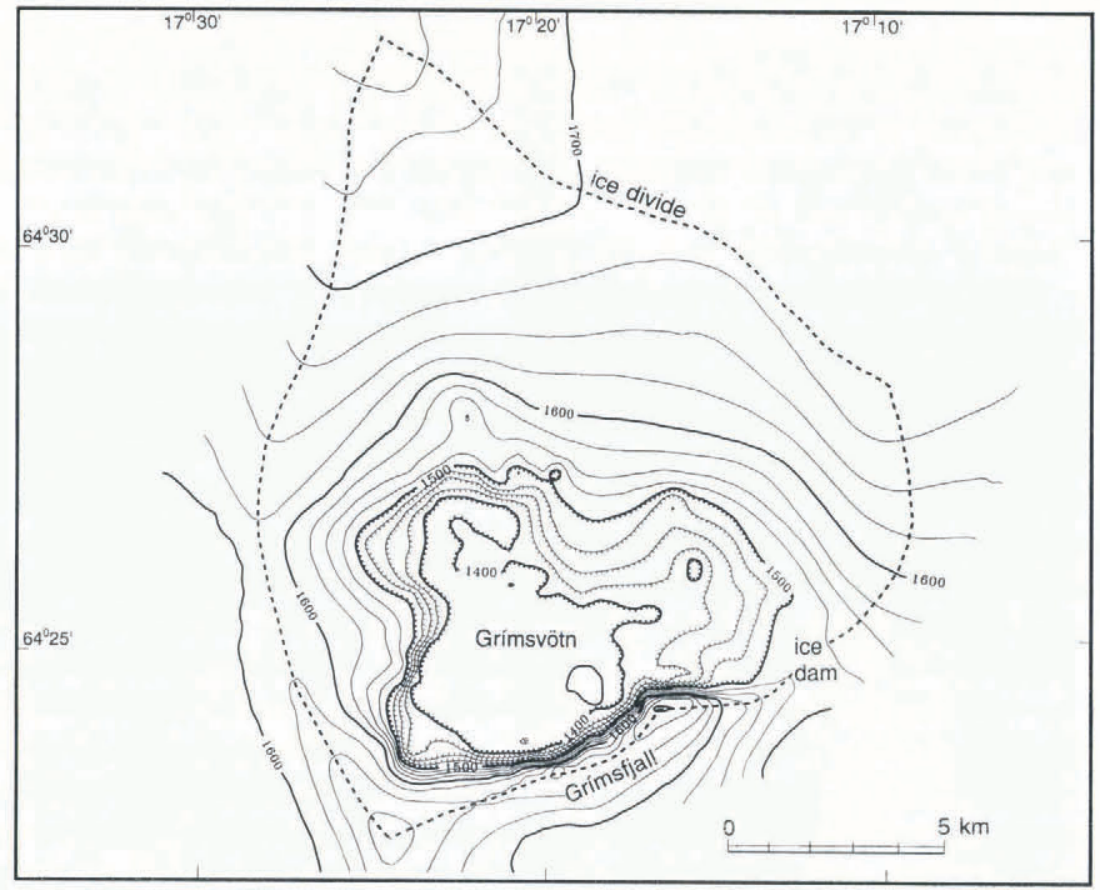

Fig. 8. Map of the ice surface in Grimsvötn in 1946 (contour interval $25 \mathrm{~m}$ ). The map is made from air pholographs using benchmarks of known height on the southern and western slopes for elevation reference. The accuracy of spatial coordinates is $100 \mathrm{~m}$ but $5 \mathrm{~m}$ in absolute heights. The relative accuracy of heights is of the order of $1 \mathrm{~m}$. The lake level was $1376 \mathrm{~m}$ a.s.l. Comparison with a map drawn by the U.S. Army Map Service (sheet .5920II, 1:50,000, Series C762), using the same set of air pholographs withoul ground-elevation control, shows that the elevations on the AMS map are in error by as much as $50 \mathrm{~m}$.

$4.8 \pm 0.7 \mathrm{~km}^{3}$ of water), yielding a mean positive massbalance rate of $0.12 \pm 0.02 \mathrm{~km}^{3} \mathrm{a}^{-1}$. Therefore, the mean rate of melting at the base of the glacier has been approximately $0.3 \mathrm{~km}^{3} \mathrm{a}^{-1}$.

\section{Water balance of the lake}

These mass-balance calculations predict that the average rate of water accumulation in the Grimsvötn lake has

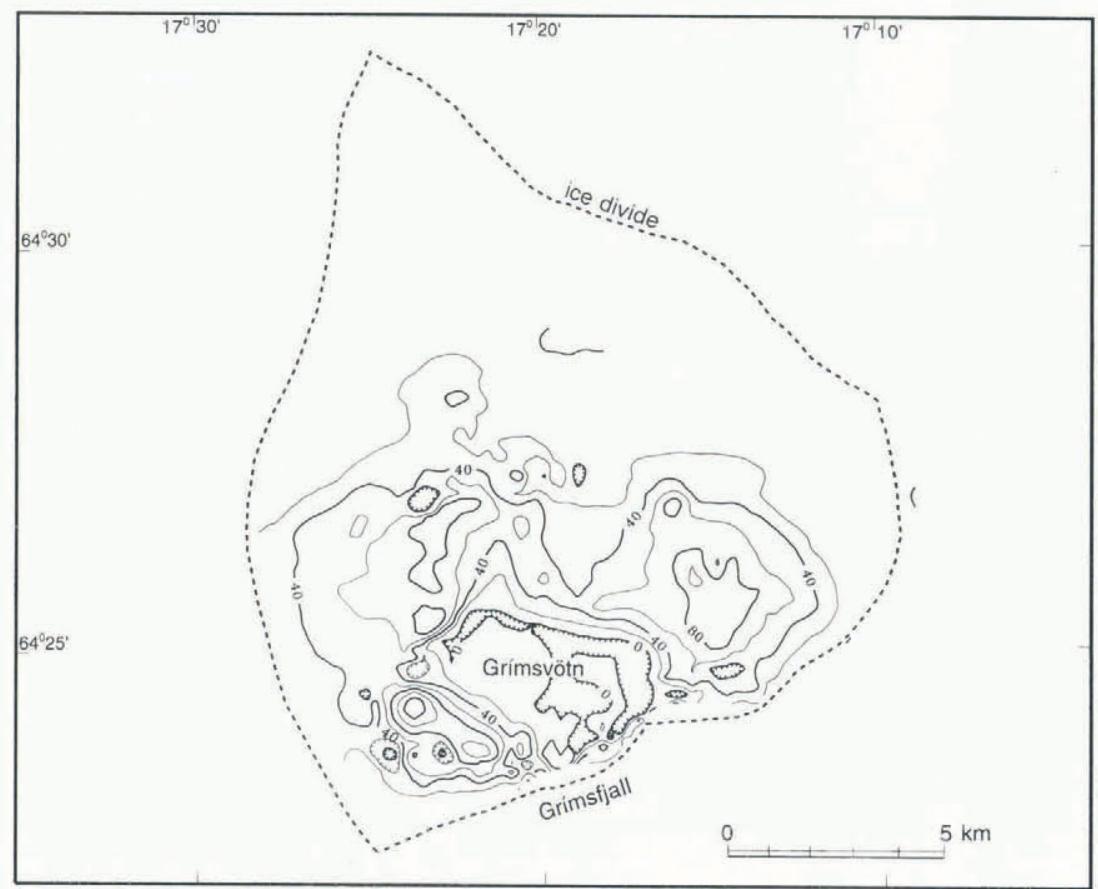

Fig. 9. Changes in ice-surface elevation in Grimsvötn between 1946 and 1987 (in metres). The map is oblained by subtracting the surface elevation in 1946 from that in 1987. The largest increases in ice thickness have occurred to the northeast, northwest and southwest of the lake. 
been $0.08-0.11 \mathrm{~km}^{3} \mathrm{a}^{-1}$ from surface melt and about $0.28 \mathrm{~km}^{3} \mathrm{a}^{-1}$ from the basal melt, or a total of 0.36 $0.38 \mathrm{~km}^{3} \mathrm{a}^{-1}$. From the data in Table 1 , the total volume of meltwater accumulation in the Grímsvötn lake for the period $1945-86$ is $15.2 \pm 0.9 \mathrm{~km}^{3}$. This equals a mean rate of accumulation of $0.37 \pm 0.02 \mathrm{~km}^{3} \mathrm{a}^{-1}$, in good agreement with that expected from the mass balance of the ice-drainage basin. This is an important result, since it shows that our record of drainage from Grimsvötn is accurate. Moreover, this supports the assumption that no net loss of ground water occurs from the Grimsvötn basin (Sigvaldason, 1965; Björnsson, 1988).

If the mass balance had been in a steady state, melt-water would have accumulated in the lake at the rate of $0.50 \mathrm{~km}^{3} \mathrm{a}$ 1 (requiring a basal melting rate of about $0.40 \mathrm{~km}^{3} \mathrm{a}^{-1}$ ). Assuming such steady state, the water volume drained by the nine jökulhlaups during this period of 41 years, would have had to have been $4 \mathrm{~km}^{3}(25 \%)$ larger than estimated from the drainage record in Table 1. Instead, this volume was stored as ice in the ice-drainage basin.

In Table 2, the period 1945-86 has been divided into four 9-11 year long intervals and the mass balance of the ice-drainage basin has been estimated from the total precipitation and the water accumulation as given by the record in Table 1. Apparently, the basin was close to steady state in 1945-54 but positive mass balance has prevailed since 1954. Moreover, the mass-balance rate was positive by $0.23 \mathrm{~km}^{3} \mathrm{a}^{-1}$ in $1976-86$, or by $1.4 \mathrm{~m} \mathrm{a}^{-1}$ averaged over the basin. These results agree with observations that indicated rapid thickening of the ice cover together with shrinkage of the lake after 1976 (Björnsson, 1988).

\section{COMPARISON WITH DISGHARGE MEASURE- MENTS}

Our record of jökulhlaup volumes may be compared to that obtained from discharge measurements in the rivers on Skeidarársandur during jökulhlaups. The use of the Manning equation by $\mathrm{R}$ ist $(1955,1973,1990)$ in 1954 72 by measuring the cross-sectional area of the river channels after the event, complemented by coarse measurements of surface velocity, seems to have yielded results that are, on average, $25 \%$ too high. The combined volume of the four jökulhlaups that occurred in this period is, according to our record, $9.9 \pm 0.8 \mathrm{~km}^{3}$, whereas Rist $(1955,1973,1990)$ obtained $12.5 \mathrm{~km}^{3}$ from his application of the Manning equation. This supports Tómasson (1974), who suggested that the discharge measurements during the jökulhlaup of 1972 yielded too high a value. Tómasson attributed the error to the fact that the channel geometry varied during the jökulhlaup in an irregular manner.

More accurate discharge measurements have been made since 1976 (Rist, 1984; Kristinsson and others, 1986; Pálsson and others, 1992; personal communication from S. Zóphóníasson, 1993) and the volumes obtained for the jökulhlaups in 1976, 1982, 1983, 1986 and 1991 are compared in Table 3 . The agreement between the two methods is quite good and well within the margin of error for all the jökulhlaups. However, our results give, on average, about a $5 \%$ smaller volume than do the discharge measurements. A systematic difference of this magnitude is not surprising considering the uncertainties of both methods. This $5 \%$ difference may be regarded as an indication of the absolute accuracy of our record, at least for the jökulhlaups after 1945 .

\section{DEGLINING VOLUME OF JÖKULHLAUPS}

In general, we have determined the volume of water in jökulhlaups from the area of the lake, the thickness of its ice cover and the water levels of the lake at the onset and the termination of bursts. For the period 1938 91, the results show a gradual decline in the volume of the jökulhlaups from Grímsvötn (Table 1). This decline results from a decreasing lake area and thickening of the ice shelf which, combined, reflect the decreasing geothermal power.

Gradually increasing triggering levels of jökulhlaups observed since 1945 (Fig. 5) are consistent with a gradual thickening of the ice dam (Fig. 10a). Exceptions do occur in jökulhlaups when warm water is involved, such as those of 1938, 1939, 1941, 1983 and possibly also 1945, 1948 and 1986 (see Björnsson, 1988, 1992; Gudmundsson and Björnsson, 1991).

Table 2. Mass balance of ice-drainage basin and the Grimsvötn lake, 1945-86

\begin{tabular}{|c|c|c|c|c|c|c|c|}
\hline \multirow{3}{*}{ Period } & \multirow[t]{3}{*}{ Interval } & \multirow{3}{*}{$\begin{array}{c}\text { Area of basin } \\
\mathrm{km}^{3}\end{array}$} & \multicolumn{2}{|c|}{ Total accumulation } & \multirow{3}{*}{$\begin{array}{c}\text { Net accumul- } \\
\text { ation } \\
\mathrm{km}^{3}\end{array}$} & \multicolumn{2}{|c|}{$\begin{array}{c}\text { Mass-balance rates of ice- } \\
\text { drainage basin }\end{array}$} \\
\hline & & & \multirow{2}{*}{$\begin{array}{c}\text { Ice-drainage } \\
\text { basin } \\
\mathrm{km}^{3}\end{array}$} & \multirow{2}{*}{$\begin{array}{c}\text { Grimsvötn lake } \\
\mathrm{km}^{3}\end{array}$} & & & \\
\hline & & & & & & $\mathrm{km}^{3} \mathrm{a}^{-1}$ & $\mathrm{ma}^{-1}$ \\
\hline $1945-54$ & 8.8 & 170 & 4.4 & 4.7 & -0.3 & -0.03 & -0.2 \\
\hline $1954-65$ & 11.2 & 170 & 5.6 & 4.3 & 1.3 & 0.12 & 0.7 \\
\hline $1965-76$ & 11.0 & 160 & 5.3 & 3.6 & 1.7 & 0.15 & 1.0 \\
\hline $1976-86$ & 10.0 & 160 & 4.7 & 2.45 & 2.25 & 0.23 & 1.4 \\
\hline $1945-86$ & 4.10 & 165 & 20.0 & 15.05 & 4.95 & 0.12 & 0.75 \\
\hline
\end{tabular}


Table 3. Comparison of jökulhlaup volumes measured in rivers on Skeiðarársandur and water volumes drained from Grimsvötn lake

\begin{tabular}{cccc}
\hline Jökulhlaup & \multicolumn{2}{c}{$\begin{array}{c}\text { Volume derived from } \\
\text { (a) Measured (b) Changes in } \\
\text { discharge } \\
\text { lake level } \\
\mathrm{km}^{3}\end{array}$} & $\begin{array}{c}\text { Difference } \\
\mathrm{km}^{3}\end{array}$ \\
\hline 1976 & $1.8-1.9$ & 1.7 & $\mathrm{~km}^{3}$ \\
1982 & 1.3 & 1.2 & $0.1-0.2$ \\
1983 & 0.55 & 0.6 & -0.05 \\
1986 & 1.2 & 1.15 & 0.05 \\
1991 & 1.55 & 1.45 & 0.1 \\
\hline
\end{tabular}

$\begin{array}{llll}1976-91 & 6.4-6.5 & 6.1 & 0.3-0.4\end{array}$

Data on discharge measurements from Rist (1984), Kristinsson and others (1986), Pálsson and others (1992) and S. Zóphóníasson (personal communication, $1993)$.

The lake level at the termination of the jökulhlaups is, on the other hand, determined by the process which closes off the water conduits. Björnsson (1974, p. 21; 1988 , p. 83) suggested that the termination of the jökulhlaups may be explained by rapid deformation of arched subglacial tunnels as the vaulted smooth roof of the ice cover of Grímsvötn falls down on the relatively flat west-facing side of the subglacial ridge bordering the lake towards the east. Our data support this, as they show that the outbursts are terminated when the bottom of the ice shelf has subsided to about $1160 \mathrm{~m}$ a.s.l. (Fig. 10b). However, since the ice shelf has thickened by about $70 \mathrm{~m}$ (Fig. 6), the lake level at the termination of jökulhlaups has risen from approximately 1300 to 1370 m a.s.l. (Fig. 10b).

\section{DISGUSSION}

We have refined and extended the record of jökulhlaup volumes for Grímsvötn since 1934, a period when large changes in geometry of the Grímsvötn ice-drainage basin occurred, together with reduction in the size of the jökulhlaups. These changes are related to the declining heat flux of the Grímsvötn volcano; climate has only played a minor role (Björnsson and Gudmundsson, 1993). It is, however, worth considering factors other than variations in volcanic activity and geothermal power which might, in the future, change the volume and frequency of jökulhlaups.

First, migration of geothermal activity towards the ice dam could lower the dam, reducing the lake level required to start jökulhlaups. Indeed, localized melting due to geothermal heat along the northeastern slopes of Grímsfjall (the dotted line in Figures 2 and 3 ) may open water courses which drain the lake at lower levels than usual, and this may have occurred in the small jökulhlaup of 1983 (Björnsson, 1988).

Secondly, changes in the surface elevation of the icedrainage basin of Skeiðarárjökull in the vicinity of the ice dam may affect the height of the dam. The retreat of the margin of Skeidarárjökull in response to a warmer climate was about $1-2 \mathrm{~km}$ in the period $1932-60$ (Eythórsson, 1963). The profile of a perfectly plastic ice cap with a basal shear stress (yield stress) of 1 bar (Paterson, 1981, p. 154) suggests that a retreat of this magnitude could lead to a $10-20 \mathrm{~m}$ thinning at the centre of an ice cap such as Vatnajökull which has a halfwidth of $50 \mathrm{~km}$. Such a lowering of the ice surface at the southern side of the ice dam would displace the centre of the dam towards the Grimsvötn lake as well as lower the dam. A lowering of the dam by about $10 \mathrm{~m}$ between 1934 and 1945 would explain the difference in the lake
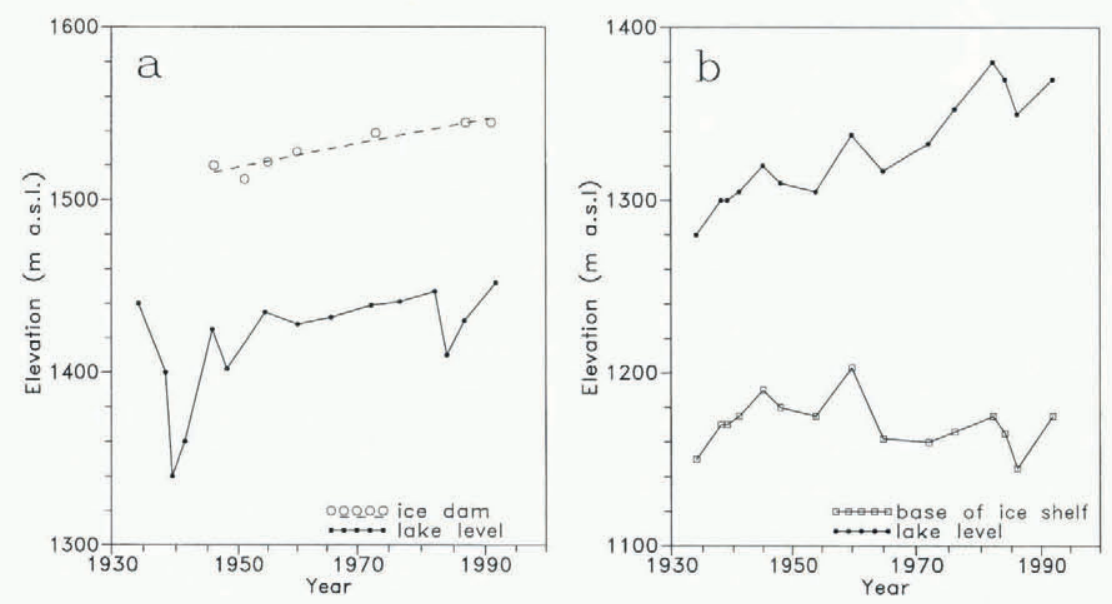

Fig. 10. (a) Elevation of the ice dam during the period 1945-91 (data for 1946-73 from levelling work by Sigurdsson (1946); Thorarinsson (1965); Rist (1990); P. Buiason (personal communication, 1993)), and the lake level at the start of jökulhlaups. The low level at the start of the jökulhlaups of 1938-48 was caused by the effects of the large eruption in 1938, while the eruption of 1983 affected the jökulhlaups in 1983 and 1986. (b) The lake level and the elevation of the base of the ice shelf at the termination of jökulhlaups. The final lake level has been rising roughly in line with increasing thickness of the ice shelf, while no such trend occurs in the elevation of the base of the ice shelf. 
level at the onset of the jökulhlaups in 1934 and 1945 (1440 and $1425 \mathrm{~m}$ a.s.l., respectively). Data gathered by expeditions in 1919 (Wadell, 1920) and 1935 (Áskelsson, 1936) suggest that the ice dam was higher at the time of these expeditions than between 1945 and 1960 (Fig. 10a). However, these data (map sketches based on sparse barometric data in 1919 and sparse trigonometric-survey data in 1935) are not sufficiently detailed to yield definite height values for the ice dam.

Thirdly, Skeiðarárjökull has surged at least twice during this century, in 1929 (personal communication from O. Sigurdsson, 1993) and in 1991. Assuming the typical behaviour of a surging glacier, it is to be expected that the surges cause a lowering of the surface of the Skeiðarárjökull basin, followed by a gradual elevation increase during the period of quiescence. It is not known how large an area was affected by the 1929 surge. Hence, whether it affected the height of the Grímsvötn ice dam is unknown. The effects of the surge of 1991 on the dam is a subject of ongoing research.

If the current period of low volcanic and geothermal activity continues, positive mass balance of the icedrainage basin in excess of $1 \mathrm{~m} \mathrm{a}^{-1}$ will ensure continued thickening of the ice shelf and the surrounding area. This should lead to a smaller lake, both in area and in volume, since, for any given lake level, a gradually larger part of the volume beneath that level would be taken up by ice. The trend of increasing elevation of the ice dam should also continue, coupled with a slight migration of the dam towards the lake. However, provided the geothermal power does not decrease below 1600-2300 MW observed since 1976 (Björnsson and Gudmundsson, 1993), the rate of melting due to geothermal heat will remain close to $0.2 \mathrm{~km}^{3} \mathrm{a}^{-1}$. Since surface melt is about $0.08 \mathrm{~km}^{3} \mathrm{a}^{-1}$, the rate of water accumulation (and the volume drained in jökulhlaups) would remain at about $0.3 \mathrm{~km}^{3} \mathrm{a}^{-1}$. This suggests that the jökulhlaups should become smaller and more frequent. If the geothermal power declines further, the jökulhlaups will become even smaller. On the other hand, were the volcanic activity to increase in the future, the enhanced melting could lead to a thinner ice shelf, thus increasing the area of the subglacial lake and, hence, its storage capacity. Conditions might again become similar to those observed earlier this century.

\section{ACKNOWLEDGEMENTS}

S. Zóphóníasson, hydrologist at the National Energy Authority, gave us access to his unpublished results on re-evaluation of the discharge measurements from the jökulhlaup of 1976. Grants from the Research Fund of the University of Iceland and the Icelandic Road Authority made this study possible. The Iceland Glaciological Society and the National Power Company provided assistance and support for field work. Constructive reviews by C. Benson, R. LeB. Hooke and J. Walder improved the quality of the paper.

\section{REFERENCES}

Ágústsdóttir, A.M., S. L. Brantley, M. T. Gudmundsson and H. Björnsson. 1992. Volatile release rates from the Grímsvötn volcano, Iceland. In Kharaka, Y. and A.S. Maest, eds. Proceedings of the 7 th International Symposium on Water-Rock Interaction. Rotterdam, A. A. Balkema, 465-468.

Áskelsson, J. 1936. On the last eruptions in Vatnajökull. Visindafélag Ísl., 18.

Björnsson, H. 1974. Explanation of jökulhlaups from Grimsvötn, Vatnajökull, Iceland. Jökull, 24, 1-26.

Björnsson, H. 1985. The winter balance in Grímsvötn, Vatnajökull, 1950-1985. Jökull, 35, 107-109.

Björnsson, H. 1988. Hydrology of ice caps in volcanic regions. Visindafélag Ísl. 45.

Björnsson, H. 1992. Jokulhlaups in Iceland: prediction, characteristics and simulation. Ann. Glaciol., 16, 95-106.

Björnsson, H. and M. T. Gudmundsson. 1993. Variations in the thermal output of the subglacial Grímsvötn caldera, Iceland. Geophys. Res. Lell., $20(19), 2127-2130$.

Björnsson, H., F. Pálsson and M.T. Gudmundsson. 1992. Vatnajökull, northwestern part. Ice surface and bedrock maps, 1:100,000. Reykjavik, University of Iceland. The National Power Company and Science Institute.

Chow, V. T., ed. 1964. Handbook of applied hydrology. New York, McGrawHill.

Clarke, G. K. C. 1982. Glacier outburst flood from "Hazard Lake", Yukon Territory, and the problem of flood magnitude prediction. $\mathcal{J}$. Glaciol., 28 (98), $3-21$.

Eythorsson, J. 1963. Variation of Iceland glaciers 1931-1960. Jökull, 13, 31-33.

Ferrari, R. L., K.J. Miller and G. Owen. 1976. The 1976 CambridgeReykjavik Universities Expedition to Vatnajökull, Iceland. Special Report No. 5. Cambridge, University of Cambridge. Department of Engineering.

Glen, J. W. 1954. The stability of ice-dammed lakes and other waterfilled holes in glaciers. J. Glaciol., 2 15), 316-318.

Gudmundsson, M.T. 1989. The Grímsvötn caldera, Vatnajökull, subglacial topography and structure of caldera infill. Jokull, 39, 1-19.

Gudmundsson, M.T. 1992. The crustal structure of the subglacial Grímsvötn volcano, Vatnajökull, Iceland, from multiparameter geophysical surveys. (Ph.D. thesis, University of London.

Gudmundsson, M.T. and H. Björnsson. 1991. Eruptions in Grimsvötn, Vatnajökull, Iceland, 1934 -1991. Jökull, 41, 21-45.

Joset, A. and J.-J. Holtzscherer. 1954. Expédition Franco-Islandaise au Vatnajökull mars-avril 1951. Résultats des sondages seismiques. Jökull, 4, 1-33.

Kristinsson, B., S. Zóphóníasson, S. Pálsson and H. Kristmannsdóttir. 1986. Hlaup a Skeidarársandi 1986. Reykjavík, National Energy Authority.

Nielsen, N. 1937. Vatnajökull - kampen mellem ild og is. Kobenhavn, H. Hagerup.

Nye, J.F. 1976. Water flow in glaciers: jökulhlaups, tunnels and veins. $\mathcal{J}$. Glaciol., 17 76), 181-207.

Pálsson, S., S. Zóphóníasson, O. Sigurdsson, H. Kristmannsdóttir and H. Adalsteinsson. 1992. Skeidarárhlaup og framhlaup Skeidarárjökuls 1991. Reykjavík, National Energy Authority.

Paterson, W. S. B. 1981. The physics of glaciers. Second edition. Oxford, etc., Pergamon Press.

Rist, S. 1955. Skeidarárhlaup 1954. Jökull, 5, 30-36.

Rist, S. 1973. Jökulhlaupaannáll 1971, 1972 og 1973. Jökull, 23, 5560. Rist, S. 1984. Jökulhlaupaannáll 1981, 1982 og 1983. Jökull, 34, 165 179.

Rist, S. 1990. Vatns er pörf. Reykjavik, Menningarsjódur.

Sigvaldason, G.E. 1965. The Grimsvötn thermal area. Chemical analysis of jökulhlaup water. Jökull, 15, 125-128.

Spring, U. and K. Hutter. 1981. Numerical studies of jökulhlaups. Cold Reg. Sci. Technol., 4(3), 221-244.

Thorarinsson, S. 1953. Some new aspects of the Grimsvötn problem. $\mathcal{J}$. Glaciol., 2 (14), 267-275.

Thorarinsson, S. 1965. Changes in the water-firn level in the Grimsvötn caldera 1954-1965. Jökull, 15, 109-119.

Thorarinsson, S. 1974. Vötnin stríd. Reykjavík, Menningarsjódur.

Tómasson, H. 1974. Grimsvatnahlaup 1972, mechanism and sediment discharge. Jökull, 24, 27-39.

Wadell, H. 1920. Vatnajökull. Some studies and observations from the greatest glacial area in Iceland. Geogr. Ann., 2(4), 300-323. 